\title{
Case Study on Building Orientation
}

\author{
Nikhil V. Deshmukh ${ }^{1}$, Yogesh P. Kherde ${ }^{2}$ \\ ${ }^{1,2}$ Assistant Professor \\ Dept. of Civil Engineering, YCCE, Nagpur, Maharashtra, India
}

\begin{abstract}
Built environment is a manifestation of the technological innovation. The way technologies are applied in design and construction of buildings, have direct implications on the amount of energy consumed. In modern context buildings represent enclosed, isolated boxes/systems where environment is artificially controlled. This requires considerable energy. With the increased awareness of energy consumption as well as the environmental impact of building operations, architects, designers and planners are required to place more consideration on sustainability and energy performance of the building. To ensure most of those considerations are reflected in the building performance, critical design decisions should be made. Buildings consume large amounts of the electricity that is generated around the world and that artificial lighting and air-conditioning consume a significant part of this energy. Furthermore, generating such electricity leads to the production of greenhouse gases. An important factor in passive architecture "Building Orientation" that can lead to savings is the amount of daylight supplied to a space as this can reduce both the artificial lighting and air-conditioning load at the same time. Our work assesses the energy savings and reducing direct solar gain by assigning proper orientation to the building from which daylight and artificial lighting are properly integrated. Such an assessment comprises firstly study of orientation that can be applied in different climatic conditions and to various buildings as per requirement. The calculation of Direct solar gain that can be obtained through this analysis identifies whether the building is properly oriented or not.
\end{abstract}

Keywords: Building Orientation, Solar Energy, Autodesk Ecotect Analysis

\section{Introduction}

The hot topic of conversation amongst global experts was how to increase energy saving measures around the world, especially in places of rapid urbanization like India. Incorporating energy efficiency measures in buildings has the potential to save $\$ 696$ billion worldwide by 2030 . India is already showing leadership in shifting the base for its entire buildings market by promoting its national Energy Conservation Building Code (ECBC). Ensuring implementation of the ECBC will allow India to save 1.7 billion $\mathrm{kWh}$ of electricity annually, equal to $0.2 \%$ of country's electricity consumption. Designers have to ensure that the design of the built form suits the intended use of the building and the specific needs of the client within the framework of the prevailing climatic conditions. In any building design, one employs simple techniques such as orientation, shading of windows, color, and vegetation among others, to create comfortable conditions. Such techniques can be very helpful to design Building Envelope. Generally, Buildings account for more than $30 \%$ of electricity consumption in India being second only to industries. It has been estimated that the total built space in the country would increase five-fold from 2005 to 2030, and by then more than $60 \%$ of the commercial built space would be air- conditioned. With every new inefficient building constructed would represent a loss of precious energy for the coming decades. It is also estimated that the urban population of the country would rise to about 590 million by the end of 2030. Thus, India has this opportunity to capture savings in buildings which are not yet built. Orientation is simply what compass direction the building faces. Does it face directly south? $80^{\circ}$ eastnortheast? Along with massing, orientation can be the most important step in providing a building with passive thermal and visual comfort. Design for orientation is a fundamental step to ensure that buildings work with the passage of the sun across the sky. Knowledge of sun paths for any site is fundamental in design building facades to let in light and passive solar gain, as well as reducing glare and overheating to the building interior.

\section{Literature Review}

Orientation is a relation which guides position and direction of building or its parts with respect to external functional factors like privacy, comfort, position, etc. A building interacts with the environment through its external faces such as walls, windows, projections, and roofs, referred to as the building envelope. The envelope acts as a thermal shell, which if thoughtlessly constructed, would result in energy leaks through every component. Hence, each component needs to be properly chosen to ensure an energy efficient building.

As per IS code No.SP-41 (S\&T) - 1987, types of climatic conditions is mainly found in India:
1. Hot and dry
2. Hot and humid
3. Warm and humid
4. Cold
5. Composite
6. Moderate Climate

\begin{tabular}{|c|c|l|}
\hline Sr. No. & \multicolumn{1}{|c|}{$\begin{array}{c}\text { Climatic } \\
\text { conditions }\end{array}$} & \multicolumn{1}{|c|}{ Preferred orientation } \\
\hline \multirow{2}{*}{ Hot and dry } & $\begin{array}{l}\text { Longer walls of building } \\
\text { should face north \& south. } \\
\text { Non-habitat rooms can be } \\
\text { located on outer faces to } \\
\text { act as thermal barrier. }\end{array}$ \\
$\begin{array}{l}\text { Preferably, the kitchen } \\
\text { should be located on } \\
\text { leeward side of the } \\
\text { building. }\end{array}$ \\
\hline 2 & Hot and humid & $\begin{array}{l}\text { The orientation and other } \\
\text { features of the building } \\
\text { would remain the same as } \\
\text { in hot and dry climatic }\end{array}$ \\
\hline
\end{tabular}




\section{International Journal of Science and Research (IJSR) \\ ISSN (Online): 2319-7064}

Index Copernicus Value (2013): 6.14 | Impact Factor (2014): 5.611

\begin{tabular}{|c|c|c|}
\hline & & zone. \\
\hline 3 & Warm and humid & $\begin{array}{l}\text { Orientation should be } \\
\text { preferably in North-South } \\
\text { direction for habitable } \\
\text { rooms i.e. longer walls } \\
\text { should face north \& south } \\
\text { so that shorter sides are } \\
\text { exposed to direct sunlight. }\end{array}$ \\
\hline 4 & Cold & $\begin{array}{l}\text { It should preferably be in } \\
\text { north - south direction i.e. } \\
\text { longer walls should face } \\
\text { north \& south to receive } \\
\text { more solar heat during } \\
\text { winter months. Windows } \\
\text { should face south to } \\
\text { facilitate direct gain. } \\
\text { Living areas can be } \\
\text { located on the southern } \\
\text { side while utility areas } \\
\text { such as stores can be on } \\
\text { the northern side. }\end{array}$ \\
\hline 5 & Composite & $\begin{array}{l}\text { An east-west orientation is } \\
\text { preferred as northern and } \\
\text { southern walls are easier } \\
\text { to shade. The surface to } \\
\text { volume ratio should be } \\
\text { kept as minimum as } \\
\text { possible to reduce heat } \\
\text { gains. }\end{array}$ \\
\hline 6 & Moderate Climate & $\begin{array}{l}\text { It is preferable to have a } \\
\text { building oriented in the } \\
\text { north-south direction. The } \\
\text { western side should } \\
\text { ideally be well-shaded. }\end{array}$ \\
\hline
\end{tabular}

\section{Methodology and Investigation}

We have chosen Rohanleher site because the orientation studies have been carried out in all the buildings of Rohanleher, Baner Road, Pune by their respective architect. It has received 7 star rating by CRISIL (Credit Rating Information Services of India Limited) and Platinum rating by DBHMS. Thus we took a particular building $\mathrm{G}$, and did the orientation analysis on it and compare with their original analysis previously done buy them. Autodesk Ecotect Analysis sustainable design analysis software is used which is comprehensive conceptto-detail sustainable building design tool. This program concerned with environments gives us opportunities to protect the environment in the generation of buildings. The following procedure is adopted while performing case study.

\section{Results}

\section{1) Direct Solar Gain at $4^{\circ}$}

The maximum solar gain on any day of the year at $4^{\circ}$ orientation of building is found to be 802931 watt-day whereas average solar gain is found to be 5725 watt-day.

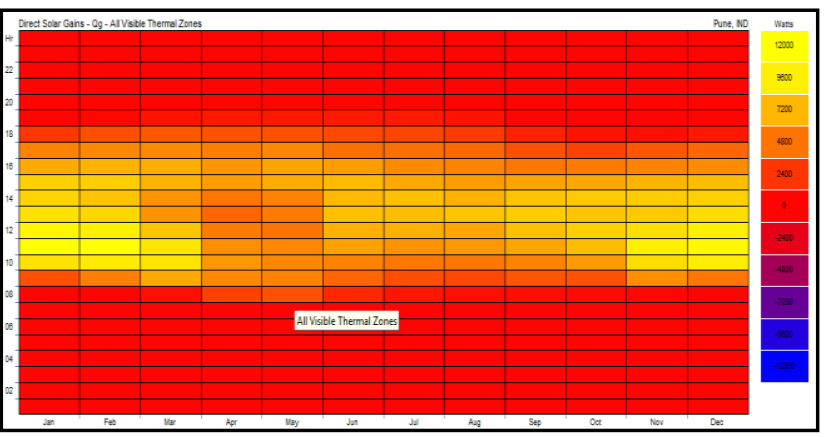

\section{2) Direct Solar Gain at $90^{\circ}$}

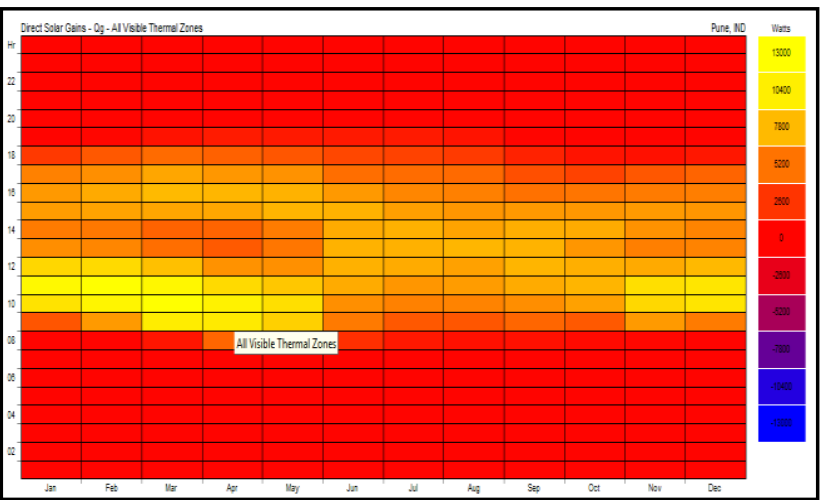

The maximum solar gain on any day of the year at $90^{\circ}$ orientation of building is found to be 801300 watt-day whereas average solar gain is found to be 5565 watt-day.

3) Direct Solar Gain at $180^{\circ}$

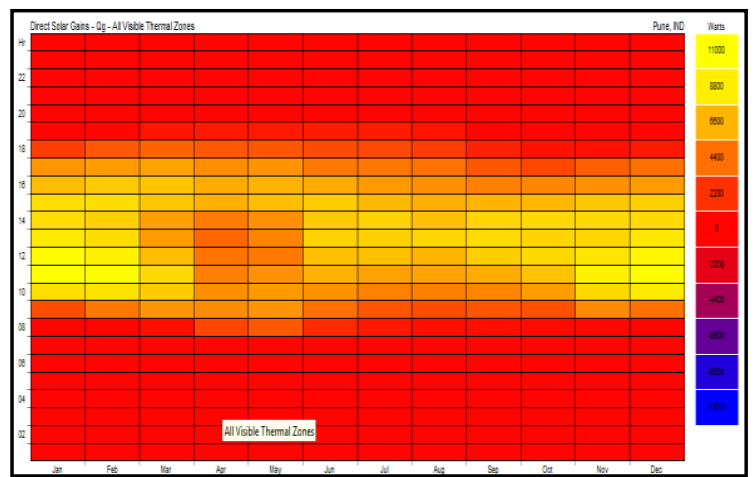

The maximum solar gain on any day of the year at $180^{\circ}$ orientation of building is found to be 736494 watt-day whereas average solar gain is found to be 5415 watt-day. 


\section{International Journal of Science and Research (IJSR) \\ ISSN (Online): 2319-7064}

Index Copernicus Value (2013): 6.14 | Impact Factor (2014): 5.611

\section{4) Direct Solar Gain at $200^{\circ}$}

The maximum solar gain on any day of the year at $200^{\circ}$ orientation of building is found to be 76089 watt-day whereas average solar gain is found to be 52930 watt-day.

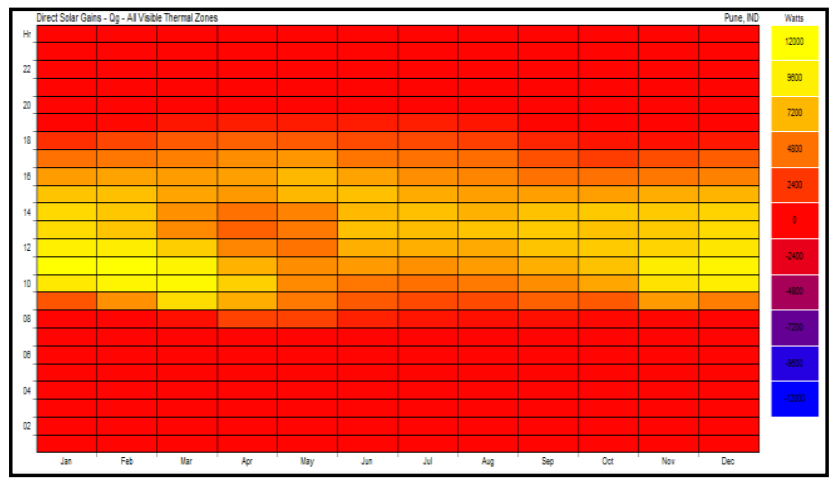

\section{5) Direct Solar Gain at $270^{\circ}$}

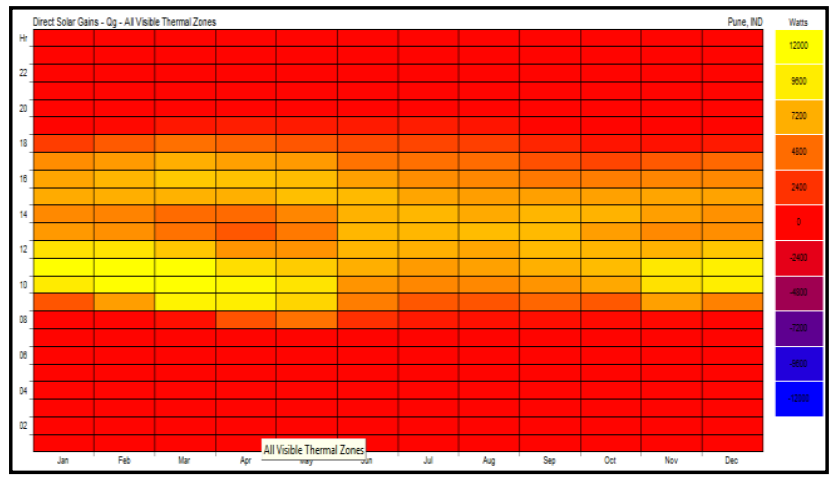

The maximum solar gain on any day of the year at $270^{\circ}$ orientation of building is found to be 80931 watt-day whereas average solar gain is found to be 5576 watt-day.

\begin{tabular}{|c|c|c|c|}
\hline $\begin{array}{c}\text { Sr. } \\
\text { No }\end{array}$ & Orientation & $\begin{array}{c}\text { Average } \\
\text { Direct Solar } \\
\text { Gain }\end{array}$ & $\begin{array}{c}\text { \% Increase Or } \\
\text { Decrease }\end{array}$ \\
\hline 1 & $\begin{array}{c}\text { At 4 Degree (as per } \\
\text { present site } \\
\text { condition) }\end{array}$ & 5725 & --- \\
\hline 2 & At 90 Degree & 5565 & $2.80 \%$ decrease \\
\hline 3 & At 180 Degree & 5415 & $5.42 \%$ decrease \\
\hline 4 & $\begin{array}{c}\text { At 200 Degree } \\
\text { (Optimum } \\
\text { Orientation) }\end{array}$ & 5293 & $7.56 \%$ decrease \\
\hline 5 & At 270 Degree & 5576 & $2.6 \%$ decrease \\
\hline
\end{tabular}

\section{Conclusion}

Buildings account for more than $30 \%$ of electricity consumption in India being second only to industries. It has been estimated that the total built space in the country would increase five-fold from 2005 to 2030, and by then more than $60 \%$ of the commercial built space would be air- conditioned. We have made a detailed study on the orientation of building and worked on it, so that how it can harness maximum daylight and reduce the heat gain by the building. In this case study we came up with conclusion that instead of existing building orienting 4 degrees from north, if would been oriented 200 degrees from north, the building would have become more energy efficient and reduction in heat will be up to $7.56 \%$ and curtail on cost consumption.

\section{References}

[1] NEUFART: Architect's Data- Third Edition.

[2] Potential of energy savings through implementation of energy conservation building code in Jaipur city, India Authors: Ankur Tulsyan, Shivraj Dhaka, Jyotirmay Mathur, Jai Vardhan Yadav.

[3] Leung Tak Shun "Effects Of Building Orientation On The Residential Property Price: An Empirical Study In Telford Garden” The University Of Hong Kong, 2010

[4] Energy Efficient Building In India by TERI- Editor: Mili Mujumdar

[5] Design guidelines by Ministry of Natural Resources

[6] Renewable Energy School Workshop: Passive Solar Building Design by Queensland Sustainable Energy Industry Development Group 